\title{
Texts from the Sheikhdom of Fakhr Al-Din Ibn Al-Kwaik Fakhr Al-Din Muhammad Bin Abdul Latif Bin Al-Kwaik (T: 769 AH / 1368 AD)
}

\author{
Dr. Abdel-Hamid Jamal Al-Farrani* \\ Professor of Islamic civilization at Al-Aqsa University in Gaza
}

*Corresponding Author: Dr. Abdel-Hamid Jamal Al-Farrani, Professor of Islamic civilization at Al-Aqsa University in Gaza

\begin{abstract}
The sheikhdoms are the mines of the biographies of biographies, their greatest lengths, and their first sources, and from their sparse blocks their great edifices were constructed, and from their bases the compilers of the encyclopedia of translation compiled their primary material (and perhaps their finishing material sometimes is not a few).

This study will discuss the talk about one of the sheikhdoms, which is "the sheikh of Fakhr al-Din Ibn alKuwaik," then I will talk about his family and then translate it to his author and what he left of the works, and then I refer to the dictionary itself, and he mentioned what was said about it in terms of its method and the content of its material, then we say those who are behind it. A high degree of significance for the loss of the copy of the author, as well as the absence of copies of the book available in the treasures of eastern and western manuscripts - as far as I know - after a long research, and on the basis of this transfer, the architecture of Al-Mujam was constructed in an approximate form of what it was, and we may have a copy of it in a meeting the days.
\end{abstract}

\section{INTRODUCTION}

Books of indexes, programs, proofs, dictionaries and sheikhdoms are synonymous names for a type of authorship that Muslims are interested in. They are the books in which the Sheikh records his narrations and books the letter he read to his sheikhs.

The books carried different names, including: the program, the index (index), the sheikhdom, the dictionary, the proof, the bond, and the restriction.

These books were given different names, which can be summed up in six terms: the sheikhdom, the lexicon, the index, the program, the proof, the bond. However, some authors used to give their books special names.

We note that the designation of a chieftain, a dictionary, a firm and a document, is most frequently used in the East. As for the Moroccans and Andalusians, it was common for them to use the word index and program.

And the sheikhdom: it includes the mention of the sheikhs whom the author met and took from them or permitted them even if he did not meet them.

It is a term used by the people of hadith. It is the book that includes the names of the sheikhs, in order to name the thing by its content, and they are sheikhs whom the author met, received various sciences from them, or received their vacations.

He used to call the word "sheikhdom" to the part in which the narrator collects the names of his sheikhs and his narrations on their behalf, then they called him after that the dictionary. When they began to single out the names of the sheikhs and arrange them according to the letters of the dictionary, the dictionaries were frequently used and launched with the sheikhdoms. And the people of Andalusia use and launch the program, but in recent centuries the people of the East say that it has been proven until now, and the people of Morocco until now call it indexing. Not all sheikhdoms have a dictionary.

\section{THE IMPORTANCE OF SHEIKHDOMS IS AS FOLLOWS}

1- It is the best way to maintain the chain of transmission in this ummah. 


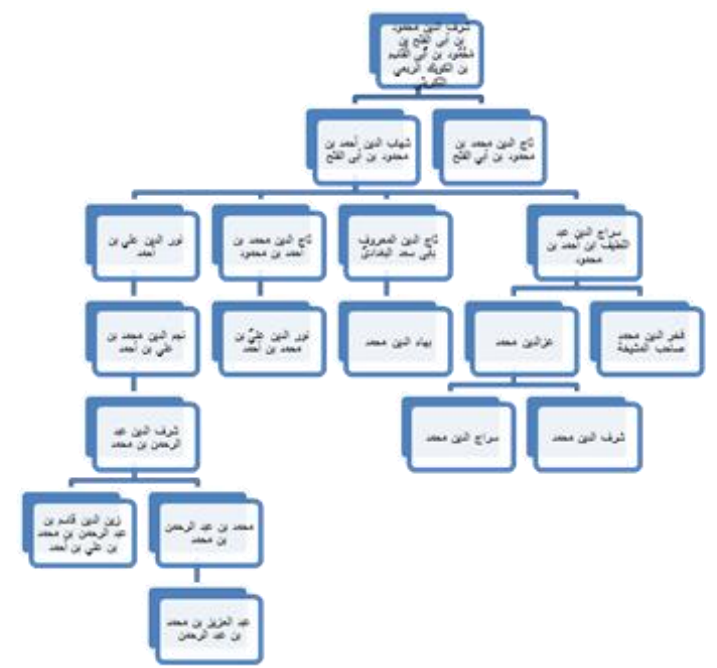

2- It is the best way to document the isnads of the ascendants of latelayer by layer, through introducing the sheikhs and translating them.

3- It is one of the strongest arguments and evidence to prove the ratio of books of the Sunnah and others to their authors.

4- That the science of sheikhdoms and evidences is a clear statement of the care of this nation, Throughout the ages and centuries, the fluctuation of conditions and the change of days, the succession of disasters and the succession of calamities, with their written heritage.

5- The sheikhdoms are the mines of the books of translations, their largest periods, and their first sources, and from their dispersed daughters the bones of their edifices were constructed, and from their minerals the compilers of translation encyclopedias collected their primary material (but perhaps their finished material sometimes not a few).

6- The books of sheikhdoms are one of the sources of the original Sunnah, due to their great attention to the narration with the chain of transmission, therefore it is one of the sources of the production of hadith and impact, and one of the books that help to preserve the Prophet's Sunnah and distinguish its authenticity from its poor, especially with the attention of many Sheikhs with a special type of narrations, which are the hadiths of benefits (From the oddity and patronage) .

Egypt and the Levant during the Mamluk era witnessed wide activity of the scientific movement with its various orientations and specializations, and this activity had an important role in the emergence of a large number of Sheikhdom books that are concerned with recording the sheikhs of the learner, and they are written by the same person or someone else in his life or after his death.

This study will deal with talking about a sheikhdom. It is the Sheikh of Fakhr al-Din Ibn al-Kwaik, so I will talk about his family, then translate to his author and what he left of the collections, then turn to the dictionary itself and list what was said about it in terms of its method and the content of its material, then we say the later ones: It is so important that the author's copy is lost; In addition to the fact that there are no copies of the book available in the coffers of eastern and western manuscripts to my knowledge - after a long search, and on the basis of these sayings I constructed the structure of the dictionary in an approximate image of what it was, and we may win a copy of it in the meeting of the days.

\subsection{Studying}

First: the Banu al-Kwik family and its role in public life

Tree of the BanuKwik family

The family of the Banu al-Kwaik, to which the owner of the sheikh Fakhr al-Din Muhammad ibnAbd al-Latif belonged, was "the house of leadership and fadl" (). It is one of the ancient commercial and scientific families., And some of them moved to Cairo, and they were merchants of generosity.

Their wealth was greatly magnified; They even came up with making loans to royalty. It is mentioned that the king of Mali, Mansa Musa () had "prepared for his expense from his country, while it is said 
that one hundred lambs of dust in each load were three vials, and they were all exhausted and unable to spend. And he decided that for him, and Siraj al-Din Ibn al-Kuwaik sent with him his minister to return to him what he had loaned from the money and he perished there, and Siraj al-Din followed him last with his son and he died there, and his son Fakhr al-Din Abu Jaafar came with some, and Musa perished before his death, but they did not gain anything from him. "

Thus, the Banu al-Kwaik were among the dignitaries of the karmic trade in the Mamluk state, and contributed to lending to foreign countries, and provided a civilized service to a Malian king who was to complete the Hajj journey after visiting Cairo.

As for the most famous members of this family, they were: Al-Sadr President Shihab Al-Din Ahmed bin Mahmoud bin Abi Al-Fath bin Mahmoud bin Abi Al-Qasim bin Al-Kwaik Al-Rabi Al-Tikrithi, a Karmic merchant, and his death was in his home in Egypt on the night of Wednesday the nineteenth of Shawwal, and he left a world wide and a property, and his children inherited it. He was one of the remnants of notable Karmic merchants (), and he is the grandfather of Fakhreddine, and he fathered four sons:

The first: Abd al-Latif bin Ahmad bin Mahmoud bin Abi al-Fath bin Mahmoud bin Abi al-Qasim alTikriti: Siraj al-Din Ibn al-Kuwaik, the Alexandrian trader al-Rabi'i was born in the year $659 \mathrm{AH}$, and heard from al-Najeeb the part of IbnArafa and it happened once, so he made a difference to everyone who heard about him a dinar dinar, and he understood the Shafi'i and the mahr And he traveled to Damascus and heard about it from Ishaq Al-Asadi, Ismail bin Maktoum, Bint Al-Bataihi and others, and he was one of the leaders of Al-Karm, and he was a virtuous good Arabic, and accurate literary goals, good form and good-naturedness, good formulas, good-minded, and from his poetry (God has made issues ... I refined it ... and I wanted a successor to go back to successor transferring him), he went to Al-Takrur in trade and died there in Jumada Al-Awwal $734 \mathrm{AH}$.

Al-Dhahabi said: "He came to us in the year of ten and seven hundred, and he heard from Fatimah bint Al-Batahi, and those present, and heard about Egypt, and Al-Thaghar.

Al-Safadi said: "He heard my reading of our sheikh who raised the religion a lot, and he used to settle me before him in a privileged place. I met with him more than once while we were attending the episode of our Sheikh Atheer al-Din, and he heard my reading a sentence, and he was the Shafi'i school of thought. And IbnMaktoum.

And he said: I stood on three verses in a handwriting that he wrote on the compiler of our scholar Sheikh al-Islam Taqi al-Din al-Subki called it "All and I have to say, which indicates:

God has raised issues that have refined them ... and they were denied successively

And when you were bound by the two conditions, you analyzed what ... the scholars were exhausted before you

Actually on the two conditions, your destiny will ascend ... the culmination of science and above that of its place.

And the second son: Muhammad bin Ahmad bin Mahmoud bin Abi al-Fath bin al-Kuwaik al-Karmi al-TikritiTaj al-Din, who was slaughtered by the thieves in his house on the night of Saturday, the sixth of Dhu al-Hijjah in $752 \mathrm{AH}$.

And the third son: Ali bin Ahmed Zain al-Din Abu Muhammad, who is mentioned below.

And the fourth son: Taj al-Din, known as Abu Saad al-Baghdadi, who used to import karma from Yemen to Egypt.

Abd al-Latif, the father of Fakhr al-Din, had two sons bearing the same name, Muhammad Fakhr alDin, who is the owner of the dictionary we are discussing, and the second: Muhammad bin Abdul Latif bin Ahmed bin Mahmoud bin Abi al-Fath al-Rabi 'bin al-Kwaik, Abu al-YamanIzz al-Din, he heard his brother's testimony from al-Rukn al-Utabi In Alexandria, from Majid bin Abd al-Majeed bin al-Sawaf, Wujihabint al-Saidi, and in Cairo from Badr al-Din bin Jama'a, Ali bin Quraysh, Ibn alSabuni, Muhammad bin Zakaria al-Suwaidi, Muhammad ibn Othman al-Tawzari, Muhammad bin Ghaly, Abu Hayyan and others, and Moheb al-Din Abu Yusef al-Tastri heard from him (), and he was He multiplied and happened a lot, and he was president, the word was heard by the judges, he died at 
the age of seventy-five years on 12 Jumada al-Awwal for the religion of hearing and narration, and he has virtue.

Izz al-Din had two sons who had the same name as well, namely: Muhammad bin Muhammad bin Abd al-Latif bin Ahmed bin Mahmoud IbnAbi al-Fatehibn al-Kuwaik al-Rabi al-Tikriti, then alIskandarani, Abu al-TaherSharaf al-Din, Sheikh al-Musnad was born in Dhul-Qi'dah in the year of seven and thirty seven hundred in Cairo, Smah- Houdora- years one of forty-seven hundred, and authorized him in the year of birth Mazzi and golden AlborzalaZainab daughter of perfection and Ali bin Ezz Omar and Ali bin Abdul MominIbnAbd al-Ibrahim bin cottage cheese and Abu Omar bin cleats and create and brought Ali Ibrahim bin Ali polar and I hear Ali Abu NaimAlosarda and Almidomi And Abu Al-Faraj Bin Abd Al-Hadiand YusefIbnJibriel Al-Mawqaa, Al-QadiEzz Al-Din IbnJama ah, and Abi Al-Haram Al-Qalansi, Likewise, Ahmad ibnKashtuhda on what was written. Judge Ezz al-Din IbnJama ', and Omar until he singled out the narration from most of his sheikhs and others. From that, Sahih Muslim in four majlis except the Seal Majlis, and he was still intermittent in his house, connected to his hearing until he died at the end of Dhu al-Qi'dah in the year $821 \mathrm{AH}$, and he had completed eighty-four years (). On the authority of one of his sheikhs, neither by hearing nor by permitting, but even in this world, he narrates about the one named from among his mentioned sheikhs.

Al-Sakhawi said: "IbnHajar, a sheikh, came out to him with a leave of absence, and Awali with hearing and leave.

It was attended by the Almidomi in the fourth series, as well as from Msmoath on Abu Faraj bin Abd al-Hadi and Abu Al-Haram Alqlansa true Muslim and Nasir al-Din Muhammad ibn Muhammad ibnAbi Tunisian section Abdul Aziz IbnAbd al-Qadir ibnAbiDur Quarterly and Ahmed bin Hafiz honor Domiaty fabricated Sunan Abu Dawood, And on Abi Al-FutuhYusef bin Muhammad Al-Dalasi Al-Shifa, and on Abraham and Muhammad and Fatimah Bani Al-Fayoumi sheikhdom of Al-Razi and Ali them and Ibrahim Al-Qutbi and Badr Al-Farqi.The hexagons of al-Razi and Ali al-Ezz bin Jama'ah were attended by the part of Ibn al-Talaya, on Abu Na'im al-Asa'di and al-Qutbi the part of IbnArafa and the part of the card to others, And from those who heard about him Al-Shifa Al-Maqrizi and mentioned him in his contracts and said that he grew up in glory and happiness, and he is one of our neighbors and the dearest of our acquaintances and our friends And the people of Egypt and Cairo descended a degree by his death, and there was no left with them after him to narrate except for the son of a group of his sheikhs, neither by hearing nor by permitting, but not in the world, who narrates on the authority of most of his sheikhs, and he is one of those who permitted the perceptive of his life.

And among those who narrated from him Sheikh Jalaluddin Al-Local, and Al-Minawi . IbnTaghriBardiJuzu al-Quduri narrated on the authority of Sheikh Radwan bin Muhammad al-Uqbi on the authority of Abu al-Taher bin al-Kwaik And he mentioned that he was "singled out for high things, and he stood up to the hearing for several years, and was delayed before his death, and he was good and still, enough for evil" .

And the second son of Izz al-Din is: Muhammad bin Muhammad bin Abd al-Latif bin Ahmed bin Mahmoud bin Abi al-Fath bin al-Kwaik Abu al-TayyebSiraj al-Din al-Iskandari, Egyptian origin, listen to Ali al-Midumi, al-Ezz bin Jamaa and others, and he is the brother of Sharaf al-Din Abu alTayyib the younger, he died in the middle of $807 \mathrm{AH}$.

Fakhr al-Din's third uncle: Ali bin Ahmad Zain al-Din Abu Muhammad gave birth to his son Muhammad, who gave birth to Abd al-Rahman, who had two sons: Qasim bin Abd al-Rahman bin Muhammad bin Ali ibn Ahmad al-Zayn Abu Muhammad al-Qahri al-Purpleh al-Shafii al-Qabbani He was born on the fifth of Dhu al-Hijjah in the year eighty-six and seven hundred, and it was said otherwise in Cairo, and he grew up there and memorized the Qur'an, then the mayor and the curriculum, and presented them to a group, and attended some lessons, And he heard Ali al-Tanukhi, IbnAbi al-Majd, al-Iraqi, al-Haythami, and General Ahmed bin Issa bin Musa al-Karaki. He was a Sufi of Said Al-Sa ada and his Sufi reciters, who died in Sha ban in the year seventy-two and was buried in the soil of the son of Zahir Bab al-Nasr.

And his brother Muhammad bin Abd al-Rahman bin Muhammad bin Ali bin Ahmed al-Qahiri alShafi'i al-Qabbani, was born on Monday the thirteenth of Jumada al-Akhira in the year eighty-one 
and seven hundred, and it was said in the year of nearly seventy-eight, and the first is more correct, in Cairo and he grew up there, so he memorized the Qur'an, al-Umda, al-Minhaj and al-Shatibiya, and presented to a group He worked a little, and heard about Al-Tanukhi, Ibn Al-Sheikha, IbnAbi AlMajd, Al-Mutruz, Al-Iraqi, Al-Haythami, Imad Ahmed bin Issa Al-Karaki, Al-Taqi Al-Dajwi and AlSharaf Bin Al-Kwaik, and you go down in the Sufism of Saeed Al-Saeeda, And he traveled to the Alexandrian thugh, then he got sick after forty year from him with his affliction also and the ants shed on him and entered under his fingernails and ate some of his flesh and silenced him without uttering, and despite that, Saber Hamid worked himself and recited until he died, and it happened before and after that, he heard from him the virtuous The sakhawi read something. He died on the last Monday, the seventh or eighteenth, Rabi'a al-Thani, in the year fifty-six AH, (), And he gave birth to his son Abd al-Aziz bin Muhammad bin Abd al-Rahman bin Muhammad bin Ali bin Ahmed al-Ezz bin alShams ibn al-Kwaik. He was born close to thirty and eight hundred in Cairo and grew up in Cairo and he memorized the Qur'an and others. From their sentence and perhaps say poetry.

And the fourth uncle of Fakhr al-Din Taj al-Din, known as Abu Saad al-Baghdadi, gave birth to a son: al-AdlBaha al-Din Muhammad bin al-Adl.

Among the notables of the family was Muhammad bin al-Hussain bin Mahmoud bin Abi al-Fath bin al-Kuwaik al-Rabi al-Tikriti, then al-MasriSharaf al-Din, a nephew of Fakhr al-Din's grandfather, who was one of the notables of the Karmic Merchants. He died next door in Mecca in the year $764 \mathrm{AH}$, and left very much money, so his son Taj al-Din Muhammad corrupted him in One year, during which it is said that he destroyed seventy thousand weights of gold.

Also among the family's notables was Muhammad bin Mahmoud bin Abi Al-Fath bin Mahmoud bin Abi Al-Qasim bin Al-Kwaik Shams Al-Din, a merchant of Tikrit, who resided in Damascus for a long time, and moved and resided in Alexandria, and he became one of the merchants of generosity, and he had a famous and well-known image in Alexandria ,He died on Dhu al-Qi'dah 28, $714 \mathrm{AH}$, and he is the uncle of Fakhr al-Din's father.

Members of this family held a number of important and sensitive positions, so Fakhreddin was the principal overseer of the Habas, and was removed from it in the year $766 \mathrm{AH}$.

And Sharaf al-Din had "suffered directorships, with the mandate of" Al-Ezz Bin Jama'ah, and several bodies in the endowments and others, with integrity and chastity, began to have him. "“ So he was grateful for them."

Abdul Aziz bin Muhammad bin Abdul Rahman bin Al-Kwaik is suffering from signing and has become one of the signatories.

This family also contributed to the urban movement in Egypt. Fakhr al-Din Abu Jaafar Muhammad bin Abd al-Latifibn al-Kwaik began building the house of IbnAbd al-Aziz, and he died and did not complete, so his wife and his cousin, Khadija, died in Rajab in the year sixty-two and seven hundredAfter him, she married Judge President Badr al-Din Hassan bin Abdul Aziz bin Abdul KarimIbnAbiTalib bin Ali bin Abdullah bin Sidhum al-Najmiy al-Sirwani, so she moved to him, and he died in the year seventy-four and seven hundred, on the twentieth of Jumada al-Awwal, and he inherited him after his death Karim Religion is his nephew .

Trader Nur al-Din Ali bin Muhammad bin Ahmad bin Mahmoud bin al-Kuwaik al-Rabi al-Tikriti renewed the Fatimid bath in the year forty-nine and seven hundred, which became known as the alKwik bath (), until the time of al-Maqrizi . He made what belonged to him from the bathroom to depend on himself, then on pineapples after him.

Al-Maqrizi mentions that the sons of Al-Kwaik, the in-laws of Judge Ezz Al-Din Abdel-Aziz Bin Jama ah, placed over the endowments of Al-Malik Al-Adil Abu BakrIbnAyyub "among other things that they placed their hands on from the endowments of the sailors of IbnJama'ah, and they took advantage of its proceeds for a period of years, then destroyed it after The year forty and seven hundred ".

The Banu al-Kuwaik also placed their hands on the Rumi bath for a period of years until they became their property Yurthan, and they are now in the hands of Sharaf al-Din Muhammad ibn Muhammad ibn al-Kwaik, and he made what belonged to him from the bath was on himself, and then on people after him . 
Attributed to Muhammad bin al-Hussein bin Mahmoud bin Abi al-Fath bin al-Kuwaik al-Rabi alTikriti, then the Egyptian Sharaf al-Din the great school in Egypt, which made it a hadith house and made many endowments for it . Abdul Latif bin Ahmed bin Mahmoud also built a school in AlThaghr.

Members of the al-Kwaik family practiced a number of trades and professions, so was Qasim bin Abdul Rahman al-Qabbani. He is gained by weight with domes, and sometimes also by sewing (). As Muhammad bin Abdul Rahman bin Al-Kwaik, she earns like his brother QasimQabbiya and dowry in it () And his son Abdul Aziz bin Muhammad bin Abdul Rahman Al-Hayek suffered for a time, then the signature became one of their sentences, and perhaps poetry would say.

Second: The author's translation.

He is Imam Muhammad bin Abd al-Latif bin Ahmad bin Mahmoud bin Abi Al-Fateh bin Mahmoud bin Abi Al-Qasim bin Al-Kwaik Al-Tikrithi Quarterly, then Al-MasryFakhr Al-Din Abu Jaafar AlFaqih Al-Muhaddad. The sources did not mention his date of birth.

Fakhr al-Din lived in Cairo, and studied in the Dome of Baybars for the hadiths (), and SahirEzz alDin bin Jama'a and his representative (), traveled with al-Ezz bin Jama'a to Medina in the year 754 $\mathrm{AH}()$, and he died on the $13^{\text {th }}$ of Ramadan in the year 769 AH.()

His elders

"Fakhr al-Din worked with the pursuit of knowledge, and he heard many of the elders of his time, and he took care of that and asked for himself more" (). From them:

1-Omar bin Muhammad bin Yahya bin Othman al-Arshi al-Atbi al-IskandaraniRukn al-Din Abu Hafs (d.724 AH) Shafi'I jurist IbnJabi al-Ahbas was born in Dhu al-Hijjah in the year 639,And he heard from the tribe of the Salafi several parts, including: Part of IbnAyaynah, Al-Dua and Al-Tawakkil, and the Sheikh Al-Sibt Al-Salafi several parts of them: Part of IbnAyyina, Al-Duaa, Al-Tawakkul, and the Sheikh of Al-Sibt, written about by the traveler, and he was a witness from him Al-Yamari, Al-Qutb Al-Halabi, Al-Dhahabi, Al-Subki, Al-Wani and others, the last of whom was Taj Al-Din Ibn Musa Al-Shafi'i And he died in zero (). 2- Yunus bin Ibrahim bin Abd al-Qawi al-Kanani al-Asqalani, then al-Masri, Fath al-Din al-Dabbisi, and it is also said al-Dabbousi (d.729 AH / 1329 CE) AlMusnad Al-Muammar, and he is the last one who spoke in Egyptian lands on the authority of Ibn AlMuqayr by hearing and with permission, and on the authority of Al-Mukhail, HamzahibnAws, and Dhafer bin Shahem, and several, and singularity, and he narrated many And he was an illiterate sheikh who dwelt in religion, and had the ability to listen to the hadith, and he was singled out for most of his sheikhs, his support was high, people benefited from it, and the students crowded over him. It has a dictionary of Al-DabousiTakhreej by Abi Al-Hussein Ahmad bin Ayb Al-Husami, and it is in six parts. IbnAybak singled out from this dictionary the companions of the Salafi in a part and then a tail on the dictionary with a tail who died in Egypt in Jumada al-Awwal and has exceeded ninety Bissir

3-Yusuf bin Omar bin Hussein bin AbiBakr al-Khatni al-Hanafi, the Egyptian Sheikh al-Muammar Badr al-Din (T.: 731 AH / 1330 CE)

He was born in the year 645 A.H. and heard from IbnRawaj, who is the seal of his companions, and from Salih Al-Medalji, Ibn Al-Lami, Abu Ali Al-Bakri, Al-Mursi, Al-Zaki Al-Mandhri, and others.

IbnHajar said: "He singled out things, and a sheikhdom came out to him on the authority of a group of sixty sheikhs and more students, who had difficulty hearing him and he could only hear for a fee, because he was fried and his wife required that and died in half a zero

-4- Ali bin Ismail bin Ibrahim bin Quraysh al-Makhzoumi, the Egyptian Taj al-Din al-Adl al-Musnad (d.732 AH)He was born in the seventh decade of Dhu al-Hijjah in the year 651 or $652 \mathrm{AH}$, and he brought Ali al-Zaki al-Mundhiri and Abd al-Muhsinibn al-Ali and heard from Muhammad ibnAnjb, al-Rashid al-Attar, the sheikh of al-Hamawi, Kamal al-Din al-Dharier, Sheikh Izz al-Din bin Abd alSalam, al-Radhiibn al-Burhan and others, and it happened a lot and he was sitting with witnesses with the religion And the goodness was narrated on him.

by Al-Suruji, Muhammad bin Rafi ', Ahmad bin Aybak al-Damiati, and the last one who spoke about him by hearing Abi Al-Faraj bin Al-Ghazi, very much a witness to the House of Weapons in Cairo, 
Al-Hafiz Zaki Al-Din called for him and said: I permitted him all that I may narrate, then he brought it with him, and it is The last one who spoke about him by hearing

5-Juwayriyah bint Ahmed bin Ahmed bin Al Hussein bin Musk bin Musa

And it is said to her Al-Hakkari, the mother of our God, was born in the fourth of Ramadan in the year 704, and I heard from Abu Al-Hassan Ibn Al-Sawaf heard from Al-Nasa'I and Musnad Al-Hamidi, and from Ali bin Isa bin Al-Qayyim what he had from the Ismaili extract, and Sufyan part, and I also heard from Al-Noor Al-Baath Al-Baath by IbnAbiDawood and others, and from Sharif Musa Sahih Muslim, and from the son of the shipment and six ministers Sahih Al-Bukhari, and from Al-HasanIbn Umar Al-Kurdi, MusnadiAbd and Al-Darmi, Al-Arba` Al-Taei, Al-Aql by Dawood Bin Al-Muhbar, and two Majlis from your literal aspirations. Abu Ja faribn al-Kuwaik wrote about it and mentioned it in his sheikhdom. He died a while before that, and some of our sheikhs and many of our peers heard from her, and she died on the twelfth of Safar in the year 783 "(). - His writings The effect of AlFakhrIbn Al-Kuwaik was not limited to teaching and the considerati 1- The dictionary of Al-EzzIbnJama'a. 2- Graduation of the Enneagrams - in the hadith (40 hadiths) by IbnJama'a. 3- The hadith of ten to ten Sheikhs from the hadith of ten of the Companions. 4- Forty selected hadiths from Sahih Muslim 5- The dictionary of its sheikhs, which I will discuss shortly.

\subsection{Sheikhdom.}

IbnHajar (d. 852 AH / 1448 CE) said: Fakhr al-Din ibn al-Kuwaik "compiled for him a lexicon and an extensive index

IbnHajar stood on it with his handwriting, and he transmitted many of the narrations from him in his book "The Lapidary Pearls," and it was narrated from him who transmitted it.

The effect of Al-FakhrIbn Al-Kuwaik was not limited to teaching and the consideration of Al-Ahbas, but he left us with a number of books, most of which are the exegesis of sheikhs and dictionaries

Regarding the title of the book, the sources did not disclose the name that the author chose for the book. Especially since it was not completely bleached, and IbnHajar mentioned the term of his sheikhs twice, and the sheikhdom of twenty one times, and the number of sheikhs mentioned by him reached (30) sheikhs, so I decided to call it "texts from the sheikhdom of Fakhr al-Din Ibn al-Kwaik."

The ratio of the book to the author was confirmed by these sources

IbnHajar al-Asqalani memorized for us we say from thirty translations from this dictionary that they were transferred from the author's version

\subsection{The method used to collect the dictionary text:}

In some areas adjacent to the west, this message was missing.

I arranged this dictionary alphabetically, and after the name of the sheikh I transmitted the text of the sheikhdom as stated by IbnHajar and translated to flags and places as far as possible, and I explained the terms in the text, and I ask Wafa Almighty to have provided a picture of what this dictionary was in its first picture written by the author.

The dictionary text: 1- Ibrahim bin Ahmed bin Isa bin Omar bin Khalid bin Abdul Mohsen bin Nashwan al-QadiBadr al-Din Ibn al-Khashab (d.775 AH) Abu Jaafaribn al-Kwaik mentioned it in his Sheikhd.

2-Ibrahim bin Ishaq bin Lu'ulQutb al-Din (d.738 AH): The grandson of the owner of Mosul, he went to Egypt, and heard from IbnHalaq, al-Najib and others, and he happened and died on the fourth decade of Shawwal in the year $738 \mathrm{AH}$.

3-Ibrahim bin Ismail bin Ibrahim bin Saad Allah bin Jamaat bin my brother, the judge Badr al-Din

IbnHajar said: “Abu Ja faribn al-Kuwaik mentioned him in his Sheikhdom.

4- Ibrahim bin Abdul Rahman bin Ibrahim bin Saad Allah bin Jama'a bin Ali bin Jamah bin HazimIbnSakhr bin Abdullah Al-Kanani Al-Hamwi Al-Qudsi origin He was born in the year 6 or $708 \mathrm{AH}$, and on the second, Abu Jaafar bin Al-Kuwaik confirmed in his sheikhdom. He heard from 
honor IbnAsaker and others, and heard in Mecca from Al-Ezz Muhammad bin AbiBakr bin Khalil and was alone on his behalf, and he wore a rag on the authority of his father on the authority of his uncle Abi Al-FathNasrallah bin Jamaa Muhammad ibn al-Furat on the authority of Abi al-Bayan, and he used to say: I don't wear it to those who attend the hearing

\section{5-Ismail bin Yaman Al-Harrani.}

He heard from Ahmad IbnShaiban Forty al-Qushayri, IbnHajar said: “Abu JaafarIbn al-Kwaik mentioned him in his Sheikhdom.

\section{6-CotwanAl-Ezzi}

He heard about Sharaf al-Din IbnAsaker, his sheikh, IbnHajar said: "Abu JaafarIbn al-Kwaik mentioned him in his sheikhdom.

\section{7-Al MalakSaif Al-Din Al-Hajj the Deputy (747 A.H.).}

His origin was from the Abalastin. When al-ZahirBaybars succeeded when he entered the country of Rum, he was one of those who were taken captive, and he gave him to al-Mansur Qalawun. AlMansur donated him to his son Ali, then he was promoted to service until he commanded. The Egyptians say to them that no other messenger will reach me, so when he returned to the kingdom, he glorified him and he was the owner of the mosque in Husayniyyah and the Al-Maliha house in the scene of Hussein and the mosque next to it. Al-Saleh Ismael brought him back to Egypt in his first condition and the deputy chief prosecutor of Egypt.

His origin was from the Abalastin. When al-ZahirBaybars succeeded when he entered the country of Rum, he was one of those who were taken captive, and he gave him to al-Mansur Qalawun. AlMansur donated him to his son Ali, then he was promoted to service until he commanded. The Egyptians say to them that no other messenger will reach me, so when he returned to the kingdom, he glorified him and he was the owner of the mosque in Husayniyyah and the Al-Maliha house in the scene of Hussein and the mosque next to it. Al-Saleh Ismael brought him back to Egypt in his first condition and the deputy chief prosecutor of Egypt.

And he was prepared to Alexandria, and he was arrested and executed in late $746 \mathrm{AH}$ or early 747 AH. IbnHajar said: "Abu Jaafaribn al-Kuwaik narrated him in his sheikhdom on one of the two springs in the year 747 AH." A soldier asked him for an increase in his fief, so he wrote to sign for him two hundred acres of red grass, and wrote on a story he asked the one who raised it to pay off the debt he owed: (And whoever takes people's debts he will pay it)

8- Abu Bakr bin Yusef bin Abd al-Azim bin Yusuf bin Ali bin Ahmed bin Dawood bin Hamid alMundhri Kamal al-Din Ibn al-Masjid al-Masri (d.741 AH)

He was born in Rajab or Shaaban in the year $647 \mathrm{AH}$, and he narrated from his father and heard from MaadiIbnAbd al-Mun'im al-Artahi a piece of the evidence of prophethood. On the sixth of Safar in the year $741 \mathrm{AH}$, and it was said that he died on the night of the twentieth of it, IbnHajar said: I saw him in the handwriting of Abu JaafarIbn al-Kwaik.

9-Balkmash bin Abdullah Al DhaheriBadr Al-Din Abu Al-Waqar (d.733 A.H.)

I hear Ali al-Najib al-Harrani and it happened that he passed away in Safar in the year $733 \mathrm{AH}$. IbnHajar said: "Abu Jaafar bin Al-Kwaik mentioned him in his sheikhdom.

10-Jinkli bin Muhammad bin Al-Baba bin Jinkali bin Khalil bin Abdullah Al-AjliBadr Al-Din (d.746 $\mathrm{AH})$

Abu JaafarIbn al-Kuwaik said, "I heard a part of him when he came to Egypt from Iraq in the year $703 \mathrm{AH}$, and he said that after him he did not leave anything like him, a religion, a mind and a presidency, and his death was in the sixth or seventeenth of Dhu al-Hijjah in $746 \mathrm{AH}$.

11-Juwayriyah bint Ahmed bin Ahmed bin Al Hussein bin Musk bin Musa

Abu JaafarIbn Al-Kwaik mentioned it in his Sheikhdom

12-Hassan bin Ahmed bin Hilal bin Saeed bin Fadlallah Al-Sarkhdi Al-SalihiBadr Al-Din Abu Muhammad, known as IbnHubal Al-Daqqaq Al-Tahan (d.779 AH) 
Al-FakhrIbn Al-Kwaik mentioned him in his sheikhdom and died a long time before him Sit jurists Fatima bint Ismail bin Ibrahim bin Quraish.

I heard from Najeeb and others, and it happened. IbnHajar said: "Ibn al-Kwaik mentioned it in his Sheikhdom“.

14-Diaa bin Othman bin Musa building nicknamed Aba Ali.

IbnHajar said: "From the sheikhdom of Ibn Al-Kwaik.

".

15-Abd al-Haq bin Muhammad bin Abdul Kafi al-Saadi (d.733 AH).

Many heard from Abd al-Hadi al-Qaisi and al-Najib, and who heard him on Abd al-HadiMusnad alThawri, the collection of AbiBishr al-Dulabi with his permission from Ahmad bin Abd al-Rahman alHusari, IbnHajar said: "Abu Ja faribn al-Kwaik said in his sheikhdom he died in Safar $733 \mathrm{AH}$

16-Abdul Latif bin Ahmed bin Mahmoud bin Abi Al-Fath bin Mahmoud bin Abi Al-Qasim (d.734 $\mathrm{AH})$

Al-Tikritian origin, Siraj Al-Din Ibn Al-Kwaik, the Alexandrian merchant Al-Rabi', IbnHajar said: "I read in the handwriting of his son, Abu Jaafar, that he died in Jumada al-Awwal 734 AH in Bilad alTakrur

17-Othman bin Shuja bin Isa Al-Damiati.

A resident of MakkahIbnHajar said: "Abu JaafarIbn Al-Kwaik mentioned it in his sheikhdom".

18-Othman bin Yusuf bin AbiBakr Al-Nuwairi Al-Maliki (d. 756 A.H.)

The righteous modern jurist, Fakhr al-Din, was born in the year $663 \mathrm{AH}$ and accompanied his father, al-Qudwa, who taught religion and understood him and other than him, dowry, fatwa, study, and most of the pilgrimage and neighborliness with solid religion, piety and sincerity. IbnHajar said: "Abu Ja 'faribn al-Kuwaik dated it on the twenty-third of Dhu al-Hijjah 756 AH."

19-Ali bin Ibrahim bin Salman Al-Naqib heard from Najeeb Al-Harrani (d.735 AH)

He was in Egypt among the narrators in the year 720 AH. IbnHajar said: "Ibn al-Kwaik chronicled his death on Safar 24, $735 \mathrm{AH}$ and said that he heard the series from him".

20-Ali bin Mohammed bin Dawood bin Delfa, MeknesiMaghribi.

Abu Jaafaribn al-Kwaik mentioned it in his sheikhdom, and he said, "Who wrote it about it"

21-Faris bin AbiFiras bin Abdullah al-Jabari al-Jawaisi Abu Muhammad (d.736 AH)

He was born after forty and heard from IbnAbd al-Daim and Abd al-HadiIbn al-Nasih, and he heard from him. He heard from him al-Barazali, al-Dhahabi and IbnRafeh, and they came out from him in their dictionaries. $736 \mathrm{H}$.

22-Muhammad bin Ahmed bin Fattouh Al Soghouni, in a neglected manner, then translated by Abu Al-Fadl (d.740 AH)

Mu in al-Din al-Iskandarani came to Damascus and asked for hadith in the year 13 and so on, and he heard from the pious Suleiman and after him, and he was a rational and virtuous religion. Alkwik in his Sheikhdom" .

23-Muhammad bin Azbek al-Badri al-KhazandariNasir al-Din al-Dimashqi (d.766 AH)

He was also called Ibn al-Daqqaq, and Ibn al-Sarim was born within the year $680 \mathrm{AH}$. I heard about Muhammad ibnAbd al-Mu'min al-Suri, and it happened. In the month of Rajab in the year 765 or 766, IbnHajar said: "Our Iraqi sheikh and others told us about him. Abu Jaafaribn al-Kuwaik dated his death in the year 6 in Rajab.

24-Muhammad bin Ismail bin Musa al-Husseini al-Sharif Taqi al-Din al-Ashqar al-Wakeel (d.731 $\mathrm{AH})$

Abu JaafarIbn al-Kwaik wrote it in its sheikhs, so it was permitted for him

25-Muhammad bin Ayyub bin Ali bin Hazem al-Dimashqi al-Shafi'I (d.737 AH)

International Journal of History and Cultural Studies (IJHCS)

Page $\mid 54$ 
The captain of the sabaa, known as Ibn al-Tahan, was born in Rabi al-Awwal in the year $652 \mathrm{AH}$, and he heard from UthmanKhatib Al-Qarafa part, and from Al-Zein Khalid, Youssef Al-Arbeli and others, and he was virtuous and of good manners. But there was a whisper in the water, and he used to understand him and read narrations, then he was disabled and cut off in the Levant, and he died in Rajab in the year 735 AH (). IbnHajar said: "And I saw in the sheikhdom of Abu JaafarIbn al-Kwaik that he died in the year $737 \mathrm{AH}$

26-Muhammad bin Dhi Al-Nun bin Omar bin Abbas bin Muhammad bin Mawhoub (d.736 AH)

Al-Asadi heard from Najeeb the third and fourth from Amali Al-Khalal mentioned by Abu Jaafar bin Al-Kwaik in his Sheikhdom, and he chronicled his death in the last ten days of Rabi` Al-Awal, 736 $\mathrm{AH}$

27-Muhammad bin Zakaria bin Yahya bin Masoud al-Maqdisi al-HanafiBadr al-Din IbnSharaf al-Din al-Wazir (he was alive in $723 \mathrm{AH}$ )

He heard from IbnMudar, Al-Najeeb and others, and it happened in the series in Alexandria in the year 723 AH. IbnHajar said: "Abu Jaafaribn al-Kwaik mentioned him in his sheikhdom".

28-Bin Sulaiman bin Abdullah bin Fadalah bin Muhammad Al-Awfi (was alive in 742 A.H.)

A resident of Mecca, Abu Mahmoud al-Qudsi wrote about it, who wrote it, looking forward to Damascus in the year $742 \mathrm{AH}$

It has descended in my heart to the village of Jalaq ... it has flames on both sides of fuel

And if my tears were not treasures, I would have ... flames for my life over that more

IbnHajar said: “Abu Ja faribn al-Kuwaik mentioned him in his Sheikhdom

29-Mohammed bin Abdullah bin Mohammed Al-AndalusiIbn Al-Sayegh

The owner of Takhmis al-BurdahIbnHajar said: "Abu Ja'faribn al-Kuwaik mentioned it in his Sheikhdom“.

30-Muhammad bin Abdul Majeed bin Khalaf bin Abd al-Wahhab bin Abdullah bin Abd al-BaqiIbn al-SawafSadiddin (722 or $723 \mathrm{AH}$ )

He heard the devotion to IbnAbi al-Dunya . On the tribe of the Salafi, Abu Jaafaribn al-Kuwaik mentioned him in his Sheikhdom and said, "I heard about him in the year $722 \mathrm{AH}$.

31-Mohammed bin Abdul Malik bin Ahmed bin Omar Al-Khilati.

Ibn al-Kwaik mentioned it in his Sheikhdom

\section{CONCLUSION}

The study reached a number of results, the most important of which were:

$\Delta$ Books of indexes, programs, proofs, dictionaries and sheikhdoms are synonymous names for a type of authorship that Muslims are interested in. They are the books in which the Sheikh records his narrations and permits, and the books he read to his sheikhs.

$\Delta$ The books of sheikhdoms were of great importance and constituted fertile material for the book of translations and flags $\Delta$

$\Delta$ Egypt and the Levant during the Mamluk era witnessed wide activity of the scientific movement with its various orientations and specializations, and this activity played an important role in the emergence of a large number of books of sheikhdoms

$\Delta$ The "Sheikhdom of Fakhr al-Din Ibn al-Kuwaik" is considered to be of a high degree of importance because of the loss of the author's copy; In addition to the absence of copies of the book available in the treasuries of eastern and western manuscripts - to the best of my knowledge - after a long search, and on the basis of these narratives I constructed the dictionary structure in an approximate image of what it was

$\Delta$ The Banu al-Kwaik family, to which the owner of the sheikh Fakhr al-Din. Muhammad ibnAbd alLatif belonged, was a "house of leadership and fadl", as it is one of the ancient commercial and scientific families 
$\Delta$ The Banu al-Kwaik were among the notables of the karmic trade in the Mamluk state, and they contributed to lending to foreign countries and provided important civilized services.

$\Delta$ A large number of the Al-Kwik family has emerged in many scientific, political, administrative and commercial fields

$\Delta$ Imam Muhammad bin Abd al-Latif bin Ahmad bin Mahmoud bin Abi Al-Fateh bin Mahmoud bin Abi Al-Qasim bin Al-Kwaik Al-Rabi Al-Tikrithi, then Al-MasryFakhr Al-Din Abu Jaafar was a jurist. The sources did not mention his date of birth

$\Delta$ Fakhr al-Din Cairo, and he studied at the Dome of Baybars for the hadiths, and SahirEzz al-Din bin Jama'a and his representative, and died on the $13^{\text {th }}$ of the month of Ramadan in the year $769 \mathrm{AH}$.

$\Delta$ Fakhreddine worked to seek knowledge, and he heard many of the elders of his time, and he took care of that, and he asked himself more.

The effect of Al-FakhrIbn Al-Kuwaik was not limited to teaching and the. Consideration of Al-AalAhbas

The sources did not disclose the name that the author chose for the book. Especially since it was not completely bleached, and IbnHajar mentioned the term of his sheikhs twice, and the sheikhdom of twenty one times, and the number of sheikhs mentioned by him reached (30) sheikhs, so I thought that I should call it "texts from the sheikhdom of Fakhr al-Din Ibn al-Kwaik".

The sources confirmed the attribution of the book to the author, and IbnHajar al-Asqalani preserved for us we say from thirty translations from this dictionary that they were transferred from the author's version....

\section{AUTHOR'S BIOGRAPHY}

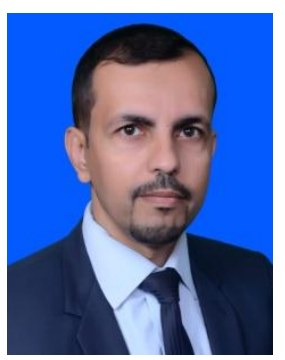

Dr. Abdul Hamid Jamal Abdul Hamid Al-Farrani. Assistant Professor of Islamic History at Al-Aqsa University in Gaza-Palestine. He has a number of refereed and published research. He participated in authoring, preparing and investigating a number of books that were printed, the last of which was the investigation of the book "Qal'id al-Aqiqan in the pride of the Ottoman state, in cooperation with Dr. Ghassan Muhammad Wishah in 2019. He participated in many local and international conferences, seminars and workshops. He is the recipient of many local and Arab scientific prizes, the most recent of which is the award of the Asian Cultural Center Award for Asian Studies - authoring and publishing category - the first session at the level of the Arab world.

Citation: Dr. Abdel-Hamid Jamal Al-Farrani. "Texts from the Sheikhdom of Fakhr Al-Din Ibn Al-Kwaik Fakhr Al-Din Muhammad Bin Abdul Latif Bin Al-Kwaik (T: 769 AH / 1368 AD)” International Journal of History and Cultural Studies (IJHCS). vol 6, no. 4, 2020, pp. 1-11. doi: DOI: https://doi.org/ 10.20431/24547654.0604002.

Copyright: (C) 2020 Authors. This is an open-access article distributed under the terms of the Creative Commons Attribution License, which permits unrestricted use, distribution, and reproduction in any medium, provided the original author and source are credited. 